\title{
ADDITIONAL INSECTS IN PENNSYLVANIAN CONCRETIONS FROM ILLINOIS
}

\author{
By F. M. Carpenter ${ }^{1}$ and Eugene S. Richardson, Jr. ${ }^{2}$
}

The ironstone nodules from the Francis Creek Shale (Middle Pennsylvanian) of Illinois continue to yield many interesting and significant insects. The specimens described in this paper were obtained in former mine pits in Grundy, Will and Kankakee Counties $^{3}$, and have been made available to us by the following collectors, who have been unusually successful in finding insects: $\mathrm{Mr}$. Jerry Herdina, Berwyn, Illinois; Mr. Joseph Makowski, Chicago; Helen and Ted Piecko, Chicago; Mr. Paul Tidd, Mendota, Illinois; and Mr. and Mrs. Francis Wolff, Park Forest, Illinois. We are most grateful to them for their cooperation in loaning their specimens to us for study and their patience in waiting for the reresults. Special thanks are extended to Mr. Jerry Herdina and to Helen and Ted Piecko for allowing us to photograph and to make a thorough examination of all the insects in their collections. Subsequent papers in this series will deal with additional specimens which they and other local collectors have found. ${ }^{4}$

The insects discussed in this paper belong to four orders: Palaeodictyoptera, Megasecoptera, Prodonata and Protorthoptera. All of these specimens are of unusual interest for one reason or another, but two of the specimens in Mr. Herdina's collection are of exceptional significance; one is the first unquestioned nymph of the order Palaeodictyoptera that has been found and the other is a brachypterous adult of a protorthopteron.

\section{Order Palaeodictyoptera Family Lycocercidae Handlirsch}

Among the Palaeodictyoptera in the collections at hand there are two species referable to the family Lycocercidae. One of these is in the Herdina collection and the other is in the Field Museum collection.

\footnotetext{
${ }^{1}$ Harvard University, Cambridge, Mass. 02138

${ }^{2}$ Field Museum of Natural History, Chicago, Illinois 60605

${ }^{3} \mathrm{Pit}$ Six is about three miles northeast of Coal City, about on the WillGrundy County line; Pit Eleven is about three miles south of Braidwood, on the Will-Kankakee County line, in northern Illinois.

${ }^{4}$ Partial financial support of this research is gratefully acknowledged to the National Science Foundation: Grant No. GB27333, F. M. Carpenter, Harvard University, principal investigator; and Grant No. GB8266, R. G. Johnson, University of Chicago, and E. S. Richardson, Jr., Field Museum of Natural History, principal investigators.
} 
The Herdina specimen is a nymph with its wing pads held obliquely away from the body (figure I). In this respect the wing pads resemble those of the megasecopterous nymph, Mischoptera douglassi, described from the same formation a few years ago (Carpenter and Richardson, 1968). However, the venation in the present nymph is sufficiently well indicated in one of the wing pads to show that the insect is a member of the Palaeodictyoptera and that it probably belongs to the family Lycocercidae. This is of unusual significance, since all of the nymphs which have previously been assigned to the Palaeodictyoptera actually belong elsewhere or have very dubious palaeodictyopterous affinities. Although until recently the family Lycocercidae has been known only from the Upper Carboniferous of Europe, it has lately been found in Pennsylvanian deposits of New Mexico (Carpenter, I97I).

\section{Genus Lycodemas, new genus ${ }^{5}$}

It seems advisable to refer this nymphal form to a separate genus rather than to assign it to one of the three genera of the family already recognized (Kukalová, 1969); the venation of the nymphal wing is not fully developed and does not provide a satisfactory concept of the adult venational pattern for comparison with the other known lycocercid species. Since the posterior media (MP) is much less developed in the nymph than it is in the known adults of $L y c o-$ cercus and the related genus Apopappus, we consider that this (i.e., the less developed MP) should be the diagnostic feature of the genus Lycodemas. The more obvious peculiarities of the nymphal wing, such as the narrow proximal region, are aspects of the immature state of its development.

Type species: Lycodemas adolescens, n. sp.

\section{Lycodemas adolescens, n.sp.}

Figures I-3

Length of fore wing pad, I I mm.; width, $3 \mathrm{~mm}$.; length of body from front of mesothorax to end of abdomen (as preserved), 26 $\mathrm{mm}$.; width of first abdominal segment, $6 \mathrm{~mm}$. The venation, as faintly indicated in a fore wing pad, is represented in figure 2. The wing sheath $(w)$ is conspicuous around the wing except in the apical region, where it is narrow. The subcosta (SC), which extends nearly to the apex of the wing, has a series of blunt projections or tubercles near the middle of the wing; these may possibly have been setal bases in the living insect. The precise origin of $R s$ from $R$ is

\footnotetext{
${ }^{5}$ The generic name is derived from a combination of lykos (wolf) and demas (body) and is considered neuter.
} 


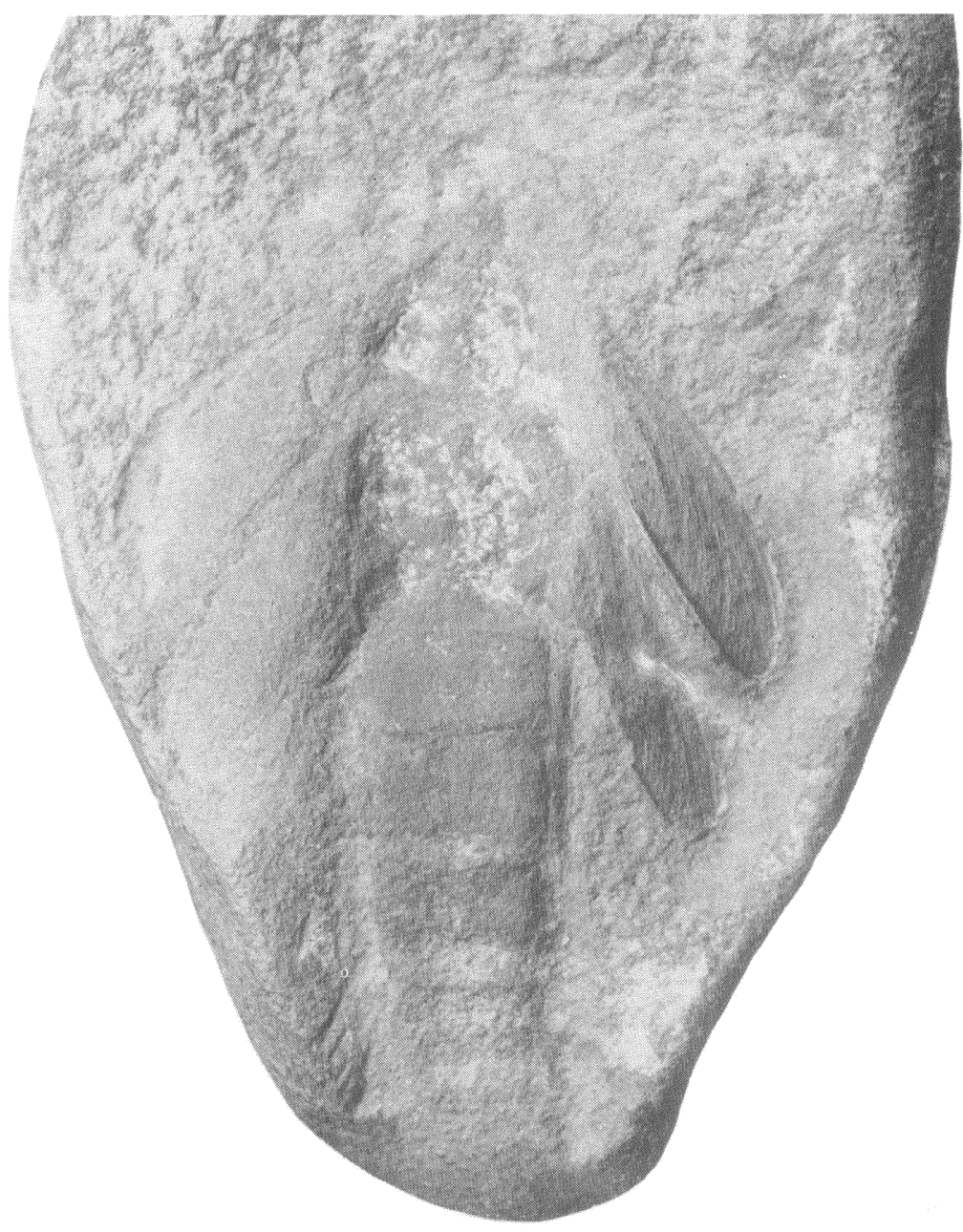

Figure 1. Lycodemas adolescens, n.sp. Photograph of holotype, No. H413, Herdina collection. 


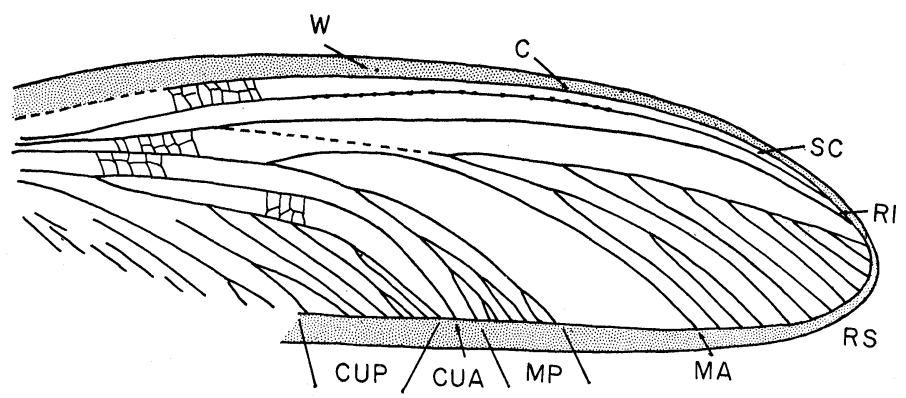

Figure 2. Lycodemas adolescens, n.sp. Drawing of holotype. W, wing sheath; other abbreviations are the conventional venational symbols.

not visible in the wing pad but it presumably arises near the basal part of the wing, as indicated in the drawing. Rs has ten primary branches, with one or two secondary branches; the area between MA and the preserved part of MP presumably had some anterior branches from MP but they are not discernible in the specimen; in any event, MP seems to be less developed than in other genera of this family. $\mathrm{CuP}$ is extensively branched and conforms to the usual pattern in the Lycocercidae. The narrow form of the wing basally is probably due to the immature nature of the wing pad. Cross veins are discernible in a few small areas; they are apparently numerous and reticulate. The general venational pattern, as far as it can be determined, is shown in figure $2 .^{6}$

The venation of the hind wing appears to be very sinilar to that of the fore wing. The wing pads on one side of the body seem somewhat broader in the photograph (figure I) than the other pair, but this is deceptive; the matrix was chipped away for some distance from these wing pads, giving the impression that the exposed area was actually part of the wing. The wing pads on both sides are $3 \mathrm{~mm}$. wide.

Holotype: No. H4I3a, b; collected in Pit Eleven; in the collection of Mr. Jerry Herdina, Berwyn, Illinois.

The most interesting feature of this nymph is the position of the wings with respect to the body. The arrangement is very similar indeed to that which we have described in the megasecopterous nymph, Mischoptera douglassi Carpenter and Richardson. As in the latter, the wing pads of Lycodemas have no contact with the body

${ }^{6} \mathrm{We}$ are indebted to Dr. Jarmila Kukalová-Peck for the preparation of this figure. 


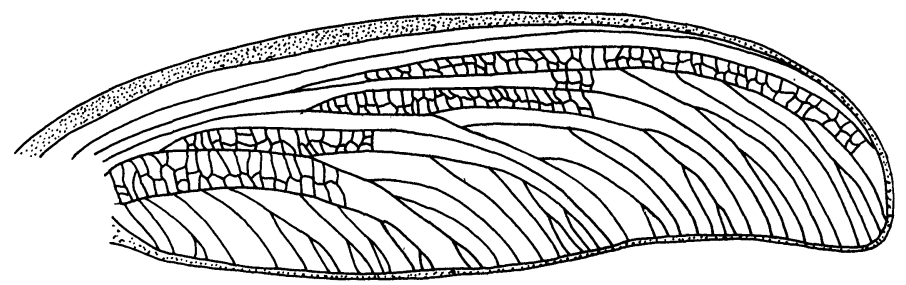

Figure 3. Lycodemas cf. adolescens. Drawing of specimen No. H110, Herdina collection.

except in the articular area of the wings themselves, in contrast to the structure of the wing pads in the nymphs of Recent insects, including those of the Ephemeroptera. A discussion of the evolutionary significance of this position of the wing pads is contained in our previous paper cited above and in Dr. Kukalovás account of the Permian may-fly nymphs ( I968).

The type of $L$. adolescens is the first nymph known that can without question be assigned to the Palaeodictyoptera; the nature of the venation in the wing pad seems to provide conclusive evidence of the palaeodictyopterous nature of the insect, especially in view of the homonomous condition of the wings. It is regrettable, of course, that more of the body structure is not preserved. What little is visible gives no indication that the nymph was modified for an aquatic existence; this is consistent with the more extensive evidence provided by the nymphs of Mischoptera for the Megasecoptera.

In the Herdina collection there is also a single wing (No. Hrio, Pit Eleven); it is obviously a nymphal wing, since it is included in a sheath (figure 3). It has a length of $27 \mathrm{~mm}$. and a maximum width of $7.5 \mathrm{~mm}$. and is therefore three times the size of adolescens. In all probability, although no proof can be given, this fossil is an older nymph of adolescens or of another species of the genus. The wing has the slightly falcate shape that is present in the mature wings of the Lycocercidae (see Kukalová, 1968, figs 33 and 34).

The specimen in the Field Museum collection is being assigned tentatively to the Lycocercidae. Assignment to this family is based on what little is preserved of the venation of one wing, probably about half the entire wing; MP is extensively branched, much more so than in the Dictyoneuridae; $\mathrm{CuA}$ is unbranched but $\mathrm{CuP}$ is well developed; the anal veins are apparently numerous. On the basis of the wings alone, especially in view of their fragmentary nature, this insect would hardly warrant formal description and nam- 


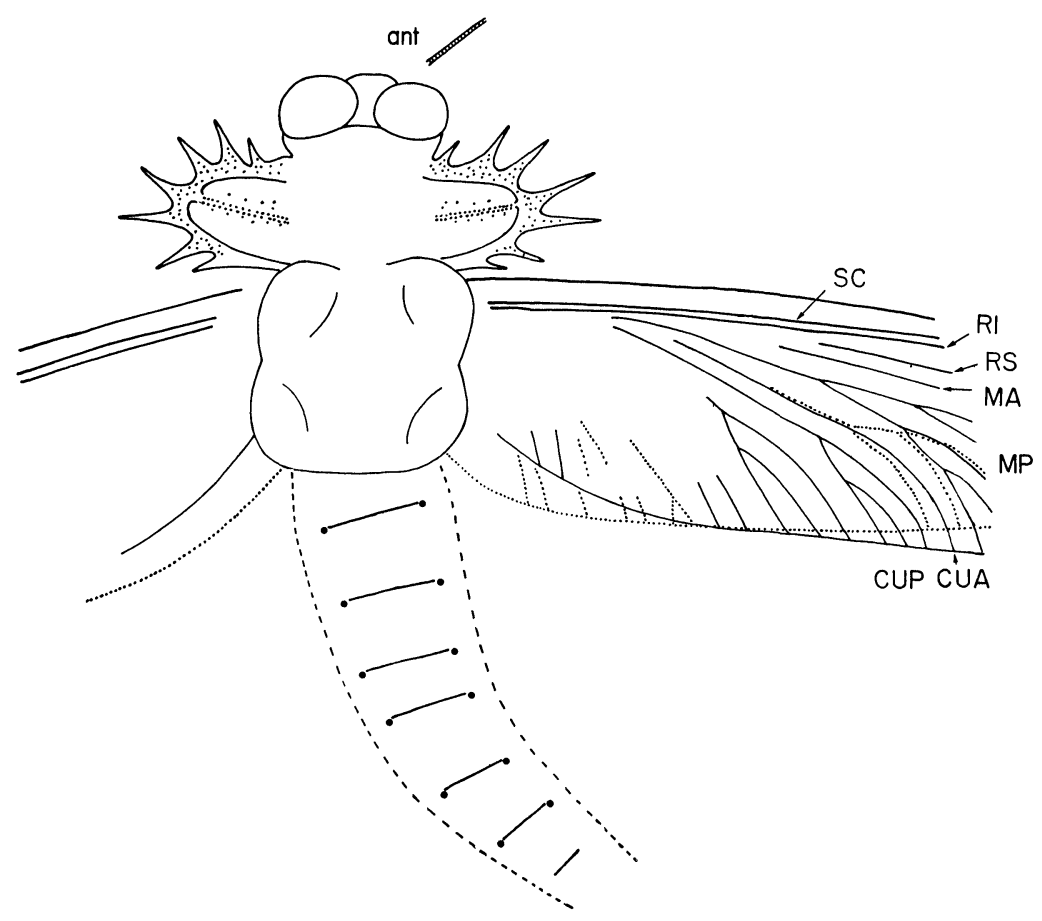

Figure 4. Notorachis wolfforum, n.sp. Drawing of holotype, No. PE 21699, Field Museum; ant, antenna; hind wing represented by dotted lines. Black circles on abdomen mark the locations of spines on the posterior edges of the tergites; the probable lateral margins of the abdomen are indicated by broken lines.

ing. However, the prothoracic lobes of this species are extraordinarily modified, nothing comparable to them having previously been observed in the Palaeodictyoptera. Since this insect is of unusual interest, generic and specific names are being assigned.

\section{Genus Notorachis, new genus ${ }^{7}$}

This genus is apparently related to Lycocercus. The outer margins of the pronotal lobes are heavily sclerotized and form a series of long spines; the more basal portion of each lobe is less sclerotized but there is a double row of blunt setae or tubercles extending transversely across each lobe (preserved as pits in the obverse). In Lyco-

\footnotetext{
${ }^{7}$ The generic name is derived from a combination of noton (back) and rachis (spine) and is considered feminine.
} 
cercus, although the lobes are prominent, they are membranous or nearly so with a radiating series of vein-like structures, as in most other Palaeodictyoptera; paranotal spines are unknown in Lycocercus.

Type species: Notorachis wolfforum, n.sp.

Notorachis wolfforum, n.sp.

Figures 4-6

Length of wings, as preserved, $22 \mathrm{~mm}$.; maximuum width of fore wing, Io $\mathrm{mm}$.; width across pronotal lobes, including spines, 20 $\mathrm{mm}$.

The fossil consists of the dorsal aspect of the head, pronotum, and meso- and metathorax; a few segments of the abdomen are indicated and the wings are outstretched in the palaeopterous position. The fore and hind wings on each side overlap but the basal part of the venation of one wing is discernible for the most part. The costal space seems to be of uniform width; the precise origin of the radial sector is not preserved; MA obviously arises before the origin of the radial sector and is probably unbranched, although its distal part is not preserved; $\mathrm{MP}$ has at least five terminal branches and $\mathrm{CuP}$ is even more extensively branched. The hind wing is almost completely covered by the fore wing and only a few veins can be distinguished.

The most conspicuous of the body structures are the pronotal lobes (figures 5 and 6), which are not sharply set off from the rest of the prothorax. The margins of the lobes are heavily sclerotized and bear seven prominent spines on each side, the first and last of these being somewhat shorter than the others. The two posterior spines of each side are directed somewhat dorsally as well as laterally. Extending along the median axis of each lobe is a double row of setae (preserved in the reverse of the fossil as fine pits). The surface of the slightly elevated margin of the pronotal lobe is smooth along the posterior edge of the lobe; on the anterior edge it is occupied by scattered setae or fine tubercles. Similar setae are present on the proximal third of all the spines. Somewhat before mid-length of each spine the setae are smaller and directed posteriorly; in the distal potion of each spine, the setae are succeeded by strong, longitudinal ridges.

The head is visible just anterior to the lobes but there is no sharp separation in the fossil between the head and thorax; two relatively large, circular structures are visible on the sides of the head, presumably the compound eyes. A four-millimeter portion of one antenna is preserved; it appears to arise from above the center of the 


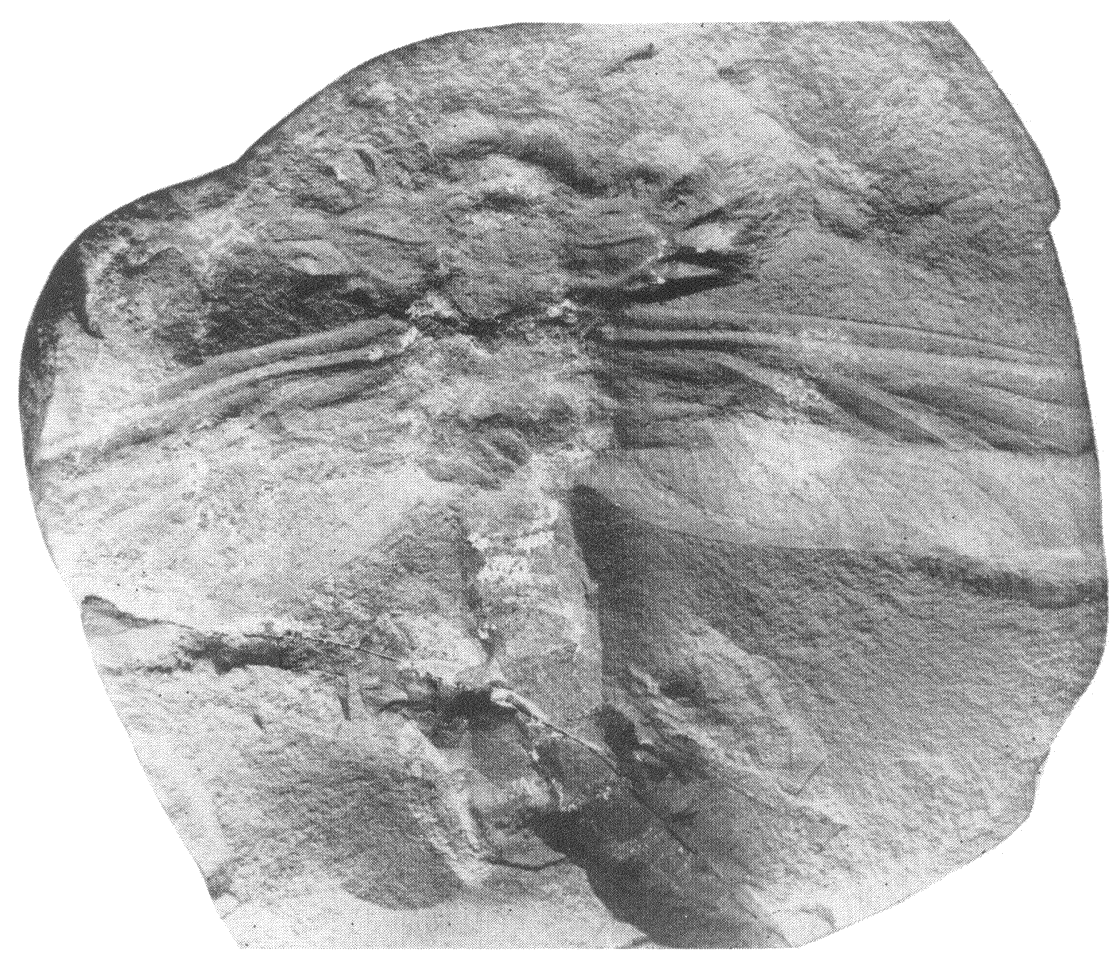

Figure 5. Notorachis wolfforum, n.sp. Photograph of holotype (reverse), showing overlapping of wings and the general form of the body.

eye and curves laterally. Its proximal segments are less than half as long as wide; the distal segments are relatively longer and are clad with fine prostrate setae. The preserved part of the antenna is surprisingly thin and delicate.

The meso- and metathorax seem to form a compact unit, each of the segments being relatively short. Portions of two segments, probably tibia and tarsus, of a weakly sclerotized fore leg, are preserved anterior to one of the pronotal lobes. The portion of the tibia is about three millimeters long and the tarsus nearly two millimeters. The tibia is armed with short spines directed distally, and the tarsus with setae. There is no reason to suppose that this leg was adapted for anything but slow walking.

The abdomen is indicated by a series of faint, transverse depressions that mark the segmentation. It is preserved for a length of 
about $23 \mathrm{~mm}$., to the edge of the nodule, and it undoubtedly originally extended beyond that point. Pairs of strong, flat, setiferous spines project dorsally and somewhat posteriorly from the abdomen, arising directly on the posterior margins of the tergites. The first spine is short; the second, third and fourth are nearly as long as the width between them; the fifth is short; a very slight projection marks the position of the sixth and there are none in the more posterior positions. These spines do not appear to mark the lateral edges of the tergites, which do not have their full widths preserved. The spines that are preserved in the fossil are about $3.5 \mathrm{~mm}$. apart laterally and were almost certainly a little to each side of the median longitudinal axis of the abdomen. Other spines along the posterior tergal margins were probably present near the sides but can only be assumed since the lateral portions of the segments are broken away. In all probability the tergal spines in Notorachis were similar to those already described in the megasecopterous Mischoptera douglassi, though the strong, dorsally projecting spines just described are flattened parallel to the body axis rather than parallel to the surface of the tergites. (See Carpenter and Richardson, 1968, p. 306). It is pertinent to note that prothoracic spines were also present in $M i s-$ choptera.

Holotype: No. PE2 1699, Field Museum of Natural History; from the collection of Mr. and Mrs. Francis A. Wolff, Park Forest, Illinois, who collected the unique specimen in Pit Eleven. The species is named for both Mr. and Mrs. Wolff.

This insect is unusual, among the Palaeodictyoptera so far known, in having elaborately modified pronotal lobes; the only other species that may approach Notorachis wolfforum in this respect is Stilbocrocis heeri (Goldenberg) (Upper Carboniferous of Germany), which is, however, a member of the Dictyoneuridae. In Stilbocrocis the lobes are smaller than in Notorachis and possess fewer spines. ${ }^{8}$

The most puzzling aspect of this fossil is the shortness of the pterothorax and the consequent overlapping of the fore and hind wings. Since this overlapping is symmetrical for both pairs of wings, it is almost certainly not due to distortion during preservation. Furthermore, the thorax itself is so short that the overlapping would

\footnotetext{
${ }^{8}$ Stilbocrocis has consistently been represented in the literature as having large pronotal lobes, bearing a series of radiating veins within the lobes themselves. From a recent examination of the type specimen (on deposit in the Natural History Museum at Bonn), I am convinced that the radiating ridges are actually spines which project beyond the edges of the lobes. A detailed account of this fossil will be published elsewhere. (FMC).
} 


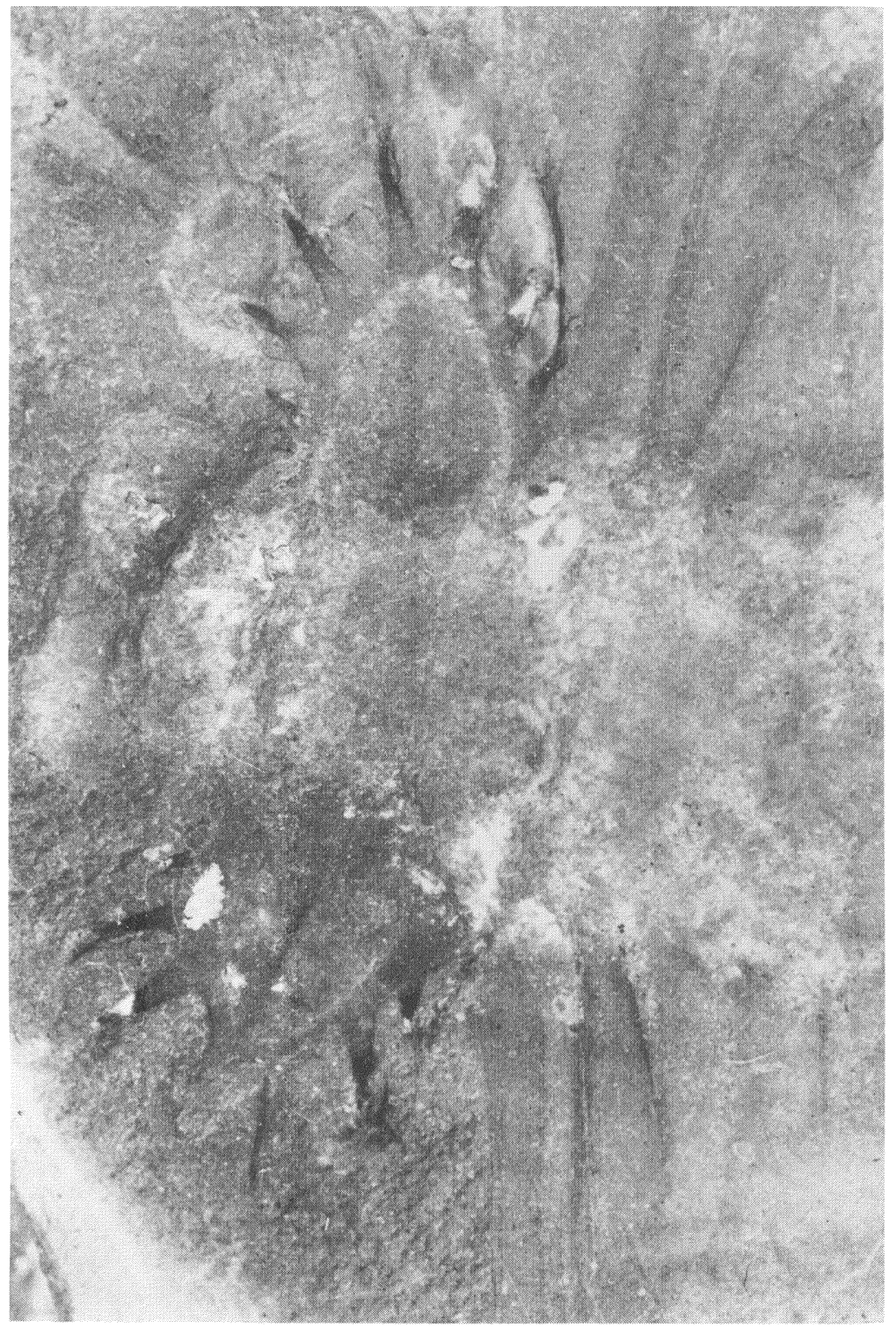

苞

용

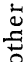

뭉

茨

:

ฮี

ฆิ

을

눈웅

㟧

담

ส

잉 궁

के

.

के के

¿

를

ปับ

용

호

중

o

文告

๑

- I

늘

$i_{10}^{\infty}$

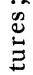




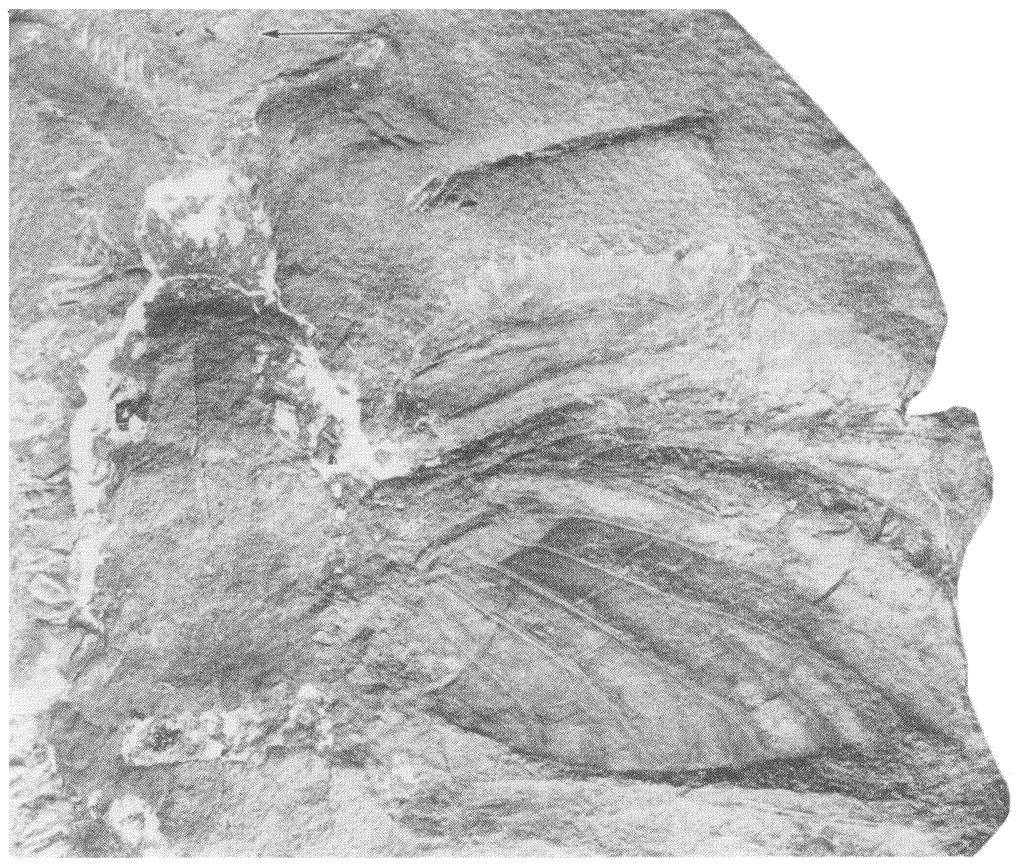

Figure 7. Homaloneura dabasinskasi Carpenter. Photograph of specimen in Tidd collection. The arrow points to the cross-section of the beak.

seem to have been unavoidable in the living insect. On the other hand, such an arrangement of the wings would seem to be very inefficient mechanically. It is in this connection interesting to note that the only other palaeodictyopteron known that shows a similar overlapping of the fore and hind wings and a comparable, short thorax, is Stilbocrocis heeri, already mentioned. This condition of the wings is readily seen in the photograph of the specimen given by Guthörl (1934), as well as in the figures by Goldenberg (1854), Schlechtendal (1912) and Guthörl (1934); it is not shown in Handlirsch's highly imaginative reconstruction of the insect (I920), in which the wings are represented in normal position. As noted above, Stilbocrocis has the wing venation characteristic of the Dictyoneuridae, whereas Notorachis has a very different venational pattern, allying it to the Lycocercidae. 


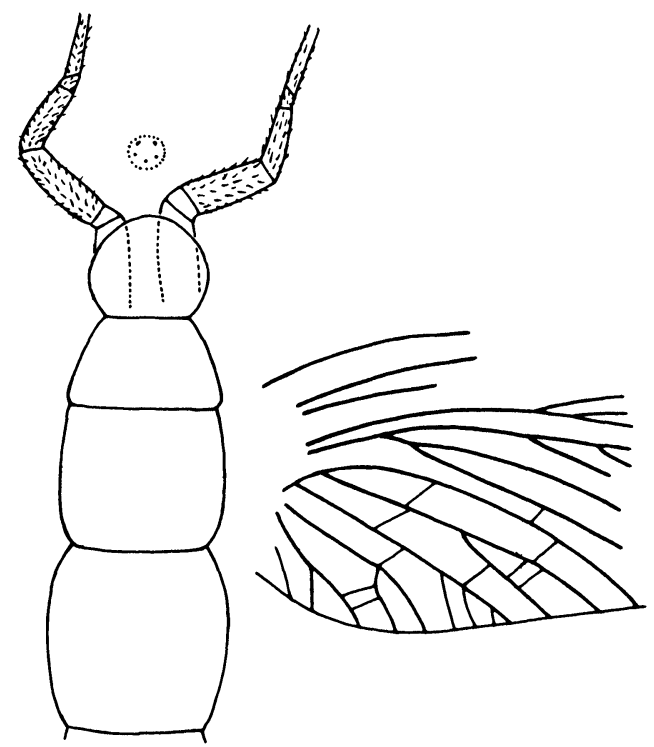

Figure 8. Homaloneura dabasinskasi Carpenter. Drawing of specimen in Tidd collection.

Family Spilapteridae Brongniart Homaloneura dabasinskasi Carpenter Figures 7-9

Homaloneura dabasinskasi Carpenter, I964: I I 7

A second specimen of this species, also in an ironstone concretion from the Francis Creek Shale, was collected in 1971, by Mr. Paul Tidd of Mendota, Illinois, in Pit Eleven and is now contained in Mr. Tidd's collection (figure 7 ) It consists of the basal part of a fore wing, portions of the head and thorax and traces of a hind wing. Determination of the species is based on the fore wing; except for minor points, such as a deeper fork on $\mathrm{CuP}$, the venation is like that of the holotype. The wing markings, characteristic of the species, are faintly preserved. Some of the thoracic structures are of interest, since they are known in only a few genera of the order. The thoracic segments are unequal (figure 8) the prothorax being slightly the smallest of them. There are no indications of the prothoracic lobes, which have previously been described in Homaloneura (Kukalová, 1969). The fore legs are preserved in the obverse half of the specimen; they are robust and possess numerous 


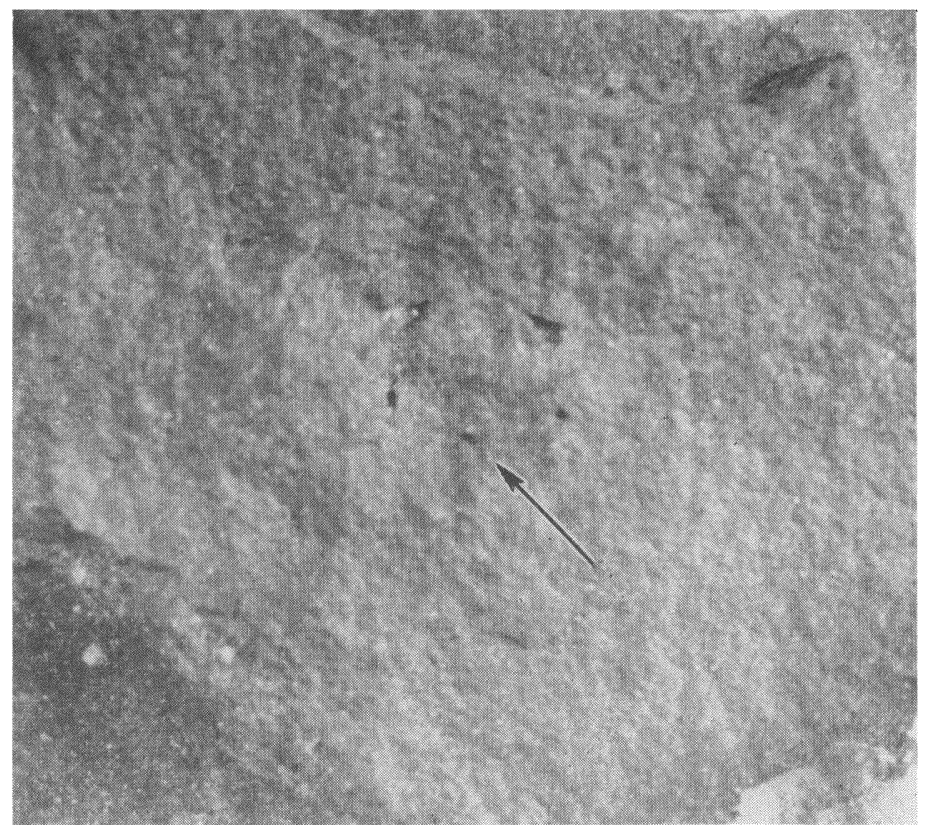

Figure 9. Homaloneura dabasinskasi Carpenter. Photograph of crosssection of beak; specimen in Tidd collection. The arrow points to the median stylet.

setae, as in other Palaeodictyoptera. The coxae are prominent and in the obverse half of the fossil extend anteriorly from the prothorax. The tarsal segmentation is not discernible, except for the first tarsomere.

The head is only vaguely indicated in the fossil (reverse half) but just anterior to the head itself there is a transverse section of the sucking beak, this being visible at the point where the two halves of the concretion separated. In order to appreciate the significance of this section, it must be borne in mind that conclusive evidence has now been provided, in the publications of Crampton (1927), Lameere (1933), Laurentiaux (1952 and 1953) and Kukalová (1969 and 1970), showing that all of the Palaeodictyoptera possessed a haustellate beak. According to observations previously made (and summarized by Kukalová, I970), the beak consisted of four slender stylets, apparently supported ventrally by a long and somewhat broader labium, usually transversely ridged. 
The beak was not directed ventrally from the head but anteriorly and ventrally.

The section of the beak in the new specimen of dabasinskasi is about $3 \mathrm{~mm}$. in front of the anterior margin of the head (figures 7 and 8$)$; it presumably shows the structure of the beak close to the head, not at a point further along the beak. As shown in the photograph (figure 9), there is a vague circular area of discoloration which appears to mark off the area of the beak. Within this can be seen sections of two pairs of stylets; these are very dark and distinct. The anterior pair, which are somewhat the larger, are presumably the mandibles, and the other pair, the maxillae. These four stylets are symmetrically arranged within the beak and with respect to each other. However, in addition to these there is a fifth stylet, midway between the maxillae and slightly more posterior. The symmetry of the pattern formed by these five structures, as seen in section, is very striking. It is virtually certain that the fifth stylet is one of the mouthparts, presumably derived from the hypopharynx; the latter, of course, is a median structure and it does function as one of the stylets of the haustellate mouth-parts of some Diptera and Hemiptera. The labium, which as noted above is broader and thicker than the stylets in the Palaeodictyoptera, is missing from the section, as are the large maxillary palpi. In any event, it now seems clear that in the spilapterid Palaeodictyoptera, at least, there were five stylets in the beaks, with an arrangement which closely parallels that in some Recent insects.

\section{Genus Spilaptera Brongniart}

In the Herdina collection there are two spilapterids that appear to belong to the same species. Only two representatives of this family have been previously reported from the Francis Creek Shale, or, in fact, from all Pennsylvanian deposits in North America: Homaloneura dabasinskasi Carpenter and Mcluckiepteron luciae Richardson. The new specimens belong to an undescribed species, which we are assigning to Spilaptera, otherwise known only from the Commentry shales of France.

Spilaptera differs from Homaloneura in having several long, sigmoidal and oblique cross veins between $\mathrm{R}_{\mathrm{I}}$ and $\mathrm{Rs}$, beyond midwing. In Homaloneura these cross veins are straight or nearly so and they are transverse, or only slightly oblique. $\mathrm{CuP}$ is usually unbranched in Homaloneura, although it may be forked distally, very near its termination. In Spilaptera $\mathrm{CuP}$ ranges from unbranched to deeply forked. The new species described below has the sigmoidal 


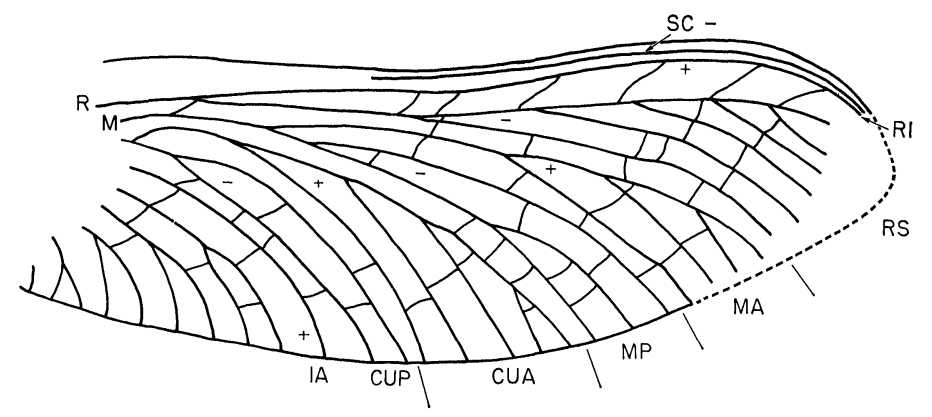

Figure 10. Spilaptera americana, n.sp. Drawing of holotype, No. H 463, Herdina collection. Length of wing as preserved, $38 \mathrm{~mm}$.

and oblique cross veins present and it is accordingly placed in the genus Spilaptera. The several other known genera of Pennsylvanian Spilapteridae, including Mcluckiepteron, have very distinctive features, such as numerous cross veins, more extensive branching of veins, pronounced tapering of wing, etc.

\section{Spilaptera americana, n.sp.}

Figure 10

Length of wing (as preserved) $38 \mathrm{~mm}$.; maximum width, $15 \mathrm{~mm}$. Costal margin distinctly concave, slightly more so than in the type species of the genus, $S$. packardi; Sc extending to wing apex; Rs with 6 terminal branches, none forked in types; MA with 4 branches, $\mathrm{CuA}$ with 5 ; $\mathrm{CuP}$ deeply forked, almost to its origin. Cross veins not numerous, about as many as in $S$. packardi, forming poorly defined rows. The sigmoidal cross veins between $\mathrm{R}_{\mathrm{I}}$ and $\mathrm{Rs}$ are long and more oblique than in $S$. packardi. The wing markings consist of darkened spots at most of the cross veins.

Holotype: No. $\mathrm{H}_{4} 63$, in the collection of Mr. Jerry Herdina, Berwyn, Illinois; collected in Pit Six. This is a very well preserved fore wing, lacking the apex and the basal region; the wing was obviously broken along the line of the cuticular thickenings, as in the type of $H$. dabasinskasi.

Paratype: No. $\mathrm{H}_{459}$, in the Herdina collection; collected in Pit Six. This consists of a less clearly preserved and more fragmentary wing; the preserved part is $33 \mathrm{~mm}$. long and I $5 \mathrm{~mm}$. wide.

Although these two specimens have virtually an identical venation, they do show one difference. As Dr. Kukalová has pointed out (1969, p. I66), the spilapterids often have some kind of supporting struc- 


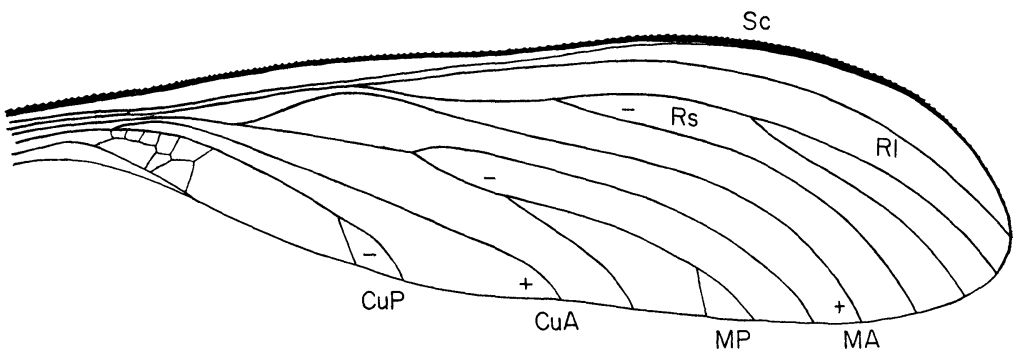

Figure 11. Eubrodia dabasinskasi Carpenter. Composite drawing of entire wing, based on specimen HTP 433, Piecko collection, and the holotype.

tures in the basal third of the wings. There is usually a thickened ridge, resembling a vein, between $\mathrm{M}$ and Rs, close to the origin of the latter and in an oblique position. From her study of the Commentry spilapterids, Dr. Kukalová concluded that the ridge was present in all Homaloneura but was absent in Spilaptera. In $S$. packardi (type species of the genus), the oblique ridge was absent, although normal transverse cross veins were present in the corresponding area of the wing. In the only other species of Spilaptera previously known (libelluloides) the nature of this particular area of the wing is unknown because that part of the wing is not preserved.

In the holotype specimen of $S$. americana, described above, the cuticular, oblique ridge is present (see figure 10), but in the paratype there is no oblique structure, only the normal cross veins. In view of the very close similarity of these two fossils in other respects, we are inclined to infer from this scant evidence that the oblique ridge is, in fact, a modified cross vein and that the degree of its inclination may vary within the species.

Order Megasecoptera

Family Brodiidae Handlirsch

Eubrodia dabasinskasi Carpenter

Figures II-I3

Eubrodia dabasinskasi Carpenter, 1967:73

In the collection of Helen and Ted Piecko, there is an interesting specimen of Eubrodia dabasinskasi, a species originally described from a single wing, lacking only the base (Carpenter, 1967). The new specimen (HTP433, Pit Eleven) consists of the body, which is 


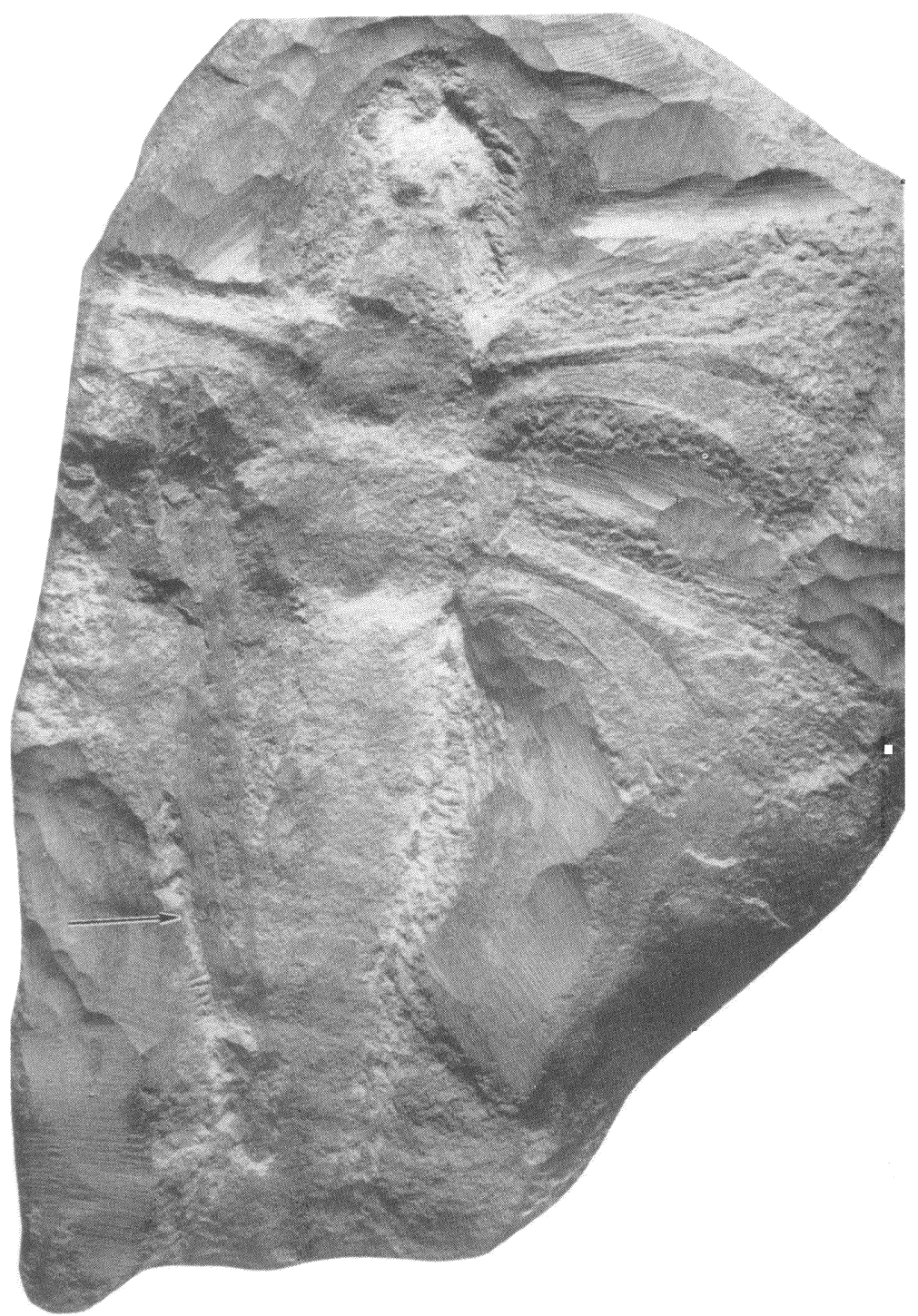

Figure 12. Eubrodia dabasinskasi Carpenter. Photograph of specimen No. HTP 433, Piecko collection; the arrow points to the filamentous structures associated with the insect. 
poorly preserved, and the basal portions of three wings. Photographic enlargement of these wing bases shows that they fit perfectly the wing of the type specimen of $E$. dabasinskasi. It is now certain that the wing of this insect was petiolate, much as in Brodia. In figure I I the wing of the holotype of dabasinskasi is combined with that of the Piecko specimen to show the entire wing. As shown in the figure, the serrated margin extends to the base of the petiole, and a definite group of reticulated cross veins occurs between IA and $\mathrm{CuP} .{ }^{9}$

The body structures of the new specimen of dabasinskasi are vaguely preserved, showing the general outline of the head, thorax and part of the abdomen (figure 12 ). The head and the thoracic segments are each $5 \mathrm{~mm}$. long.

What makes the specimen of special interest is the presence of several very long, filamentous structures that rest along one side of the abdomen and extend anteriorly to about the level of the fore wing (figure 13). We assumed at first that these were of plant origin, but two paleobotanists, Dr. Sergius Mamay of the U. S. Geological Survey, and Professor Elso Barghoorn of Harvard University, both well acquainted with Upper Carboniferous plants, have expressed their convictions, after examination of the specimen, that the filaments were not parts of plants. As preserved, these structures are not carbonized but have the same surface texture, including the rugosity, as the brodiid integument. Similar but fewer filaments were associated with the megasecopterous nymph (Mischoptera douglassi), already described from the ironstone nodules (Carpenter and Richardson, 1969). Furthermore, Dr. Jarmila Kukalová-Peck informs us that such filaments are associated with the specimens of Megasecoptera in the Upper Carboniferous shales of Commentry, France, and with Palaeodictyoptera which she has collected in the Permian deposits of Moravia. Although it is difficult to see how these filaments can be part of the insects concerned, judgment on this possibility should wait until Dr. Kukalová-Peck has published on the evidence obtained from the study of the European material at her disposal.

\section{Order Protodonata}

A specimen of this order was collected in an ironstone nodule by Mr. Joseph Makowski, of Chicago. It is of unusual interest, since the Protodonata have previously been represented in the Francis

\footnotetext{
${ }^{9}$ The cross veins in the rest of the wing of Eubrodia are shown in the photograph of the holotype (Carpenter, 1967, p. 67).
} 


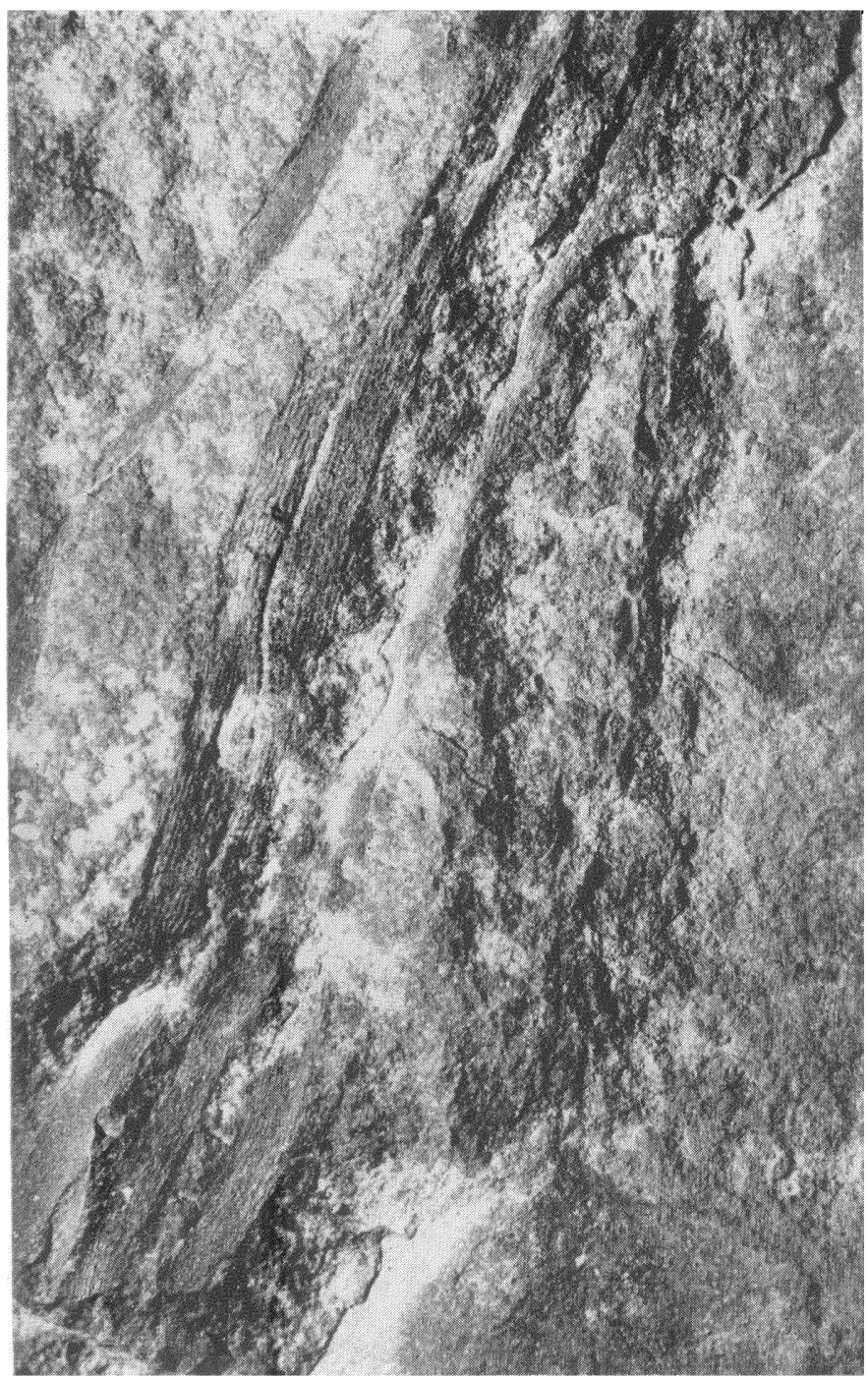

Figure 13. Eubrodia dabasinskasi Carpenter. Photograph of filamentous structures associated with specimen No. HTP 433, Piecko collection. 


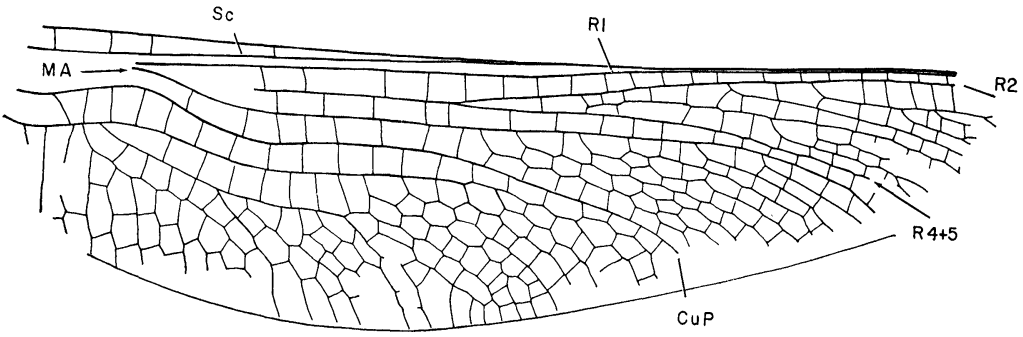

Figure 14. Oligotypus makowskii, n.sp. Drawing of holotype, No. IWJM-I-C, Makowski collection. Length of wing as preserved, $65 \mathrm{~mm}$.

Creek shales by only a single species, Paralogopsis longipes Handlirsch. The new fossil clearly belongs to the family Paralogidae.

\section{Family Paralogidae Handlirsch}

This family is characterized by having the subcosta terminate at about mid-wing, instead of extending to the wing apex, as in other families of protodonates; and by having $\mathrm{R}_{2}+3$ and $\mathrm{R}_{4}+5$ widely divergent. Two genera are known: Paralogus Scudder, from Upper Carboniferous shales (Allegheny Series) of Rhode Island, and Oligotypus Carpenter from Lower Permian deposits in Kansas and Oklahoma. The new fossil is referable to Oligotypus.

\section{Oligotypus makowskii, n.sp.}

Figure 14

Length of wing, as preserved, $65 \mathrm{~mm}$.; maximum width, $18 \mathrm{~mm}$.; estimated complete length, $90 \mathrm{~mm}$. Similar to the type species of the genus, tillyardi, but with the first forking of Rs occurring basal of the termination of $\mathrm{Sc}$; with the area between $\mathrm{MA}$ and $\mathrm{CuP}$ about twice as wide as it is in tillyardi; and with the hind margin of the wing more strongly curved than in tillyardi. The cross veins are not so numerous as in tillyardi and the cellules formed by the cross veins are a little larger than, and not so numerous as, in tillyardi. Other venational details are shown in figure I4.

Holotype: No. IWJM-I-C, in the collection of Mr. Joseph Makowski, Chicago; collected in Pit Eleven. The specimen consists of about three-fourths of a wing; it is very well preserved, with the convexities and concavities of the veins very distinct. The application of water or alcohol brings out the cross veins very distinctly. It is not possible to determine with certainly whether the fossil is a fore or hind wing; the strongly convex margin suggests the latter. 
Handlirsch's Paralogopsis longipes, also from the ironstone nodules, may belong to the family Paralogidae, as suggested by Handlirsch (I9II). However, since the species is known only from a small fragment that lacks the areas of the wings including the structures indicative of the family, we consider any attempt to make family assignment really futile. In fact, Handlirsch's publication of generic and specific names for such a small fragment is regrettable, for it is doubtful that even a good specimen of the insect, if one were ever found, could be rcognized as conspecific with his type. In any event, should longipes turn out to belong to the Paralogidae, obvious differences in the origins of $\mathrm{RI}_{\mathrm{I}}, \mathrm{Rs}$ and $\mathrm{MA}$, and in the branching of IA, separate that species from makowskii.

\section{Order Protothoptera}

Included in the Herdina collection is a specimen of a remarkable protorthopteron, which appears to be a brachypterous adult. Its venational pattern, which is similar in both fore and hind wings, resembles very closely that of the Cacurgidae, but in its total structure the insect represents an undescribed family.

\section{Family Herdinidae, new family}

This is related to the Cacurgidae on the basis of the following venational features: $\mathrm{CuA}$ and MP are fused basally and $\mathrm{CuP}$ is forked at least once, with its more anterior branch coalescing with $\mathrm{CuA}$. The distinctive characteristics of the new family are as follows: the base of the costal area is strongly sclerotized and is without veins; $S c$ and $\mathrm{R}_{\mathrm{I}}$ teminate well before the apex of the wing; Rs arises at about mid-wing, with at least two main branches; MP diverges from the stem of $\mathrm{CuA}$ well before mid-wing and gives rise to at least one main branch. Cross veins are numerous and they form, with longitudinal veins, a coarse net-work over the entire wing. The hind wing is much smaller than the fore wing but with the exception of the narrow costal area the venational pattern is similar to that of the fore wing; there is no anal fan or enlarged anal area. Small tubercles are distributed over the longitudinal and cross veins of both the fore and hind wings. The prothorax was apparently large and possessed a cordate shield.

This family is readily distinguished from the Cacurgidae by the reticulate nature of the cross veins and by having Rs much less extensively developed, in addition to the obvious differences in the form of the fore wing 


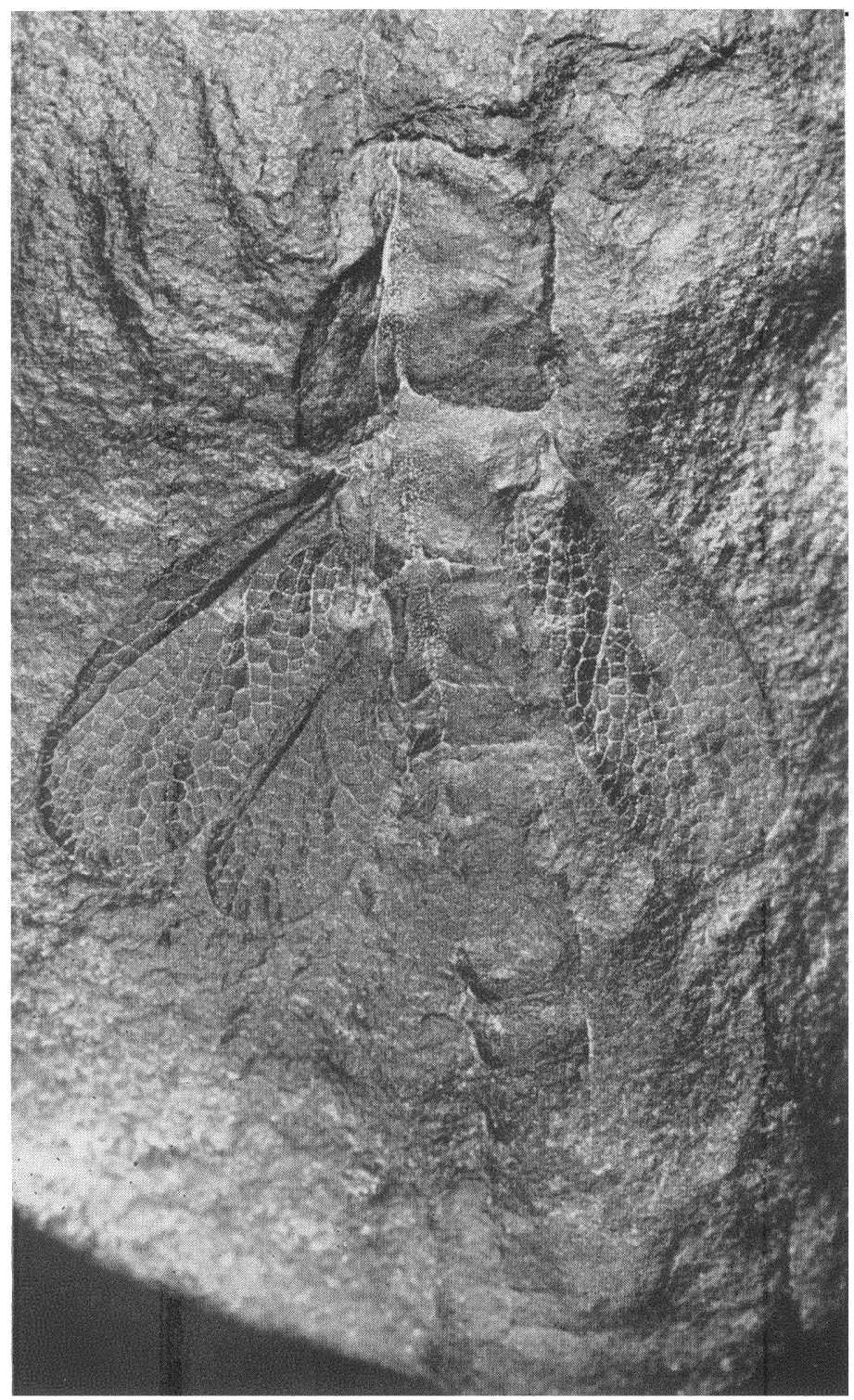

Figure 15. Herdina mirificus, n.sp. Photograph of holotype, No. H 412a, Herdina collection (obverse). 


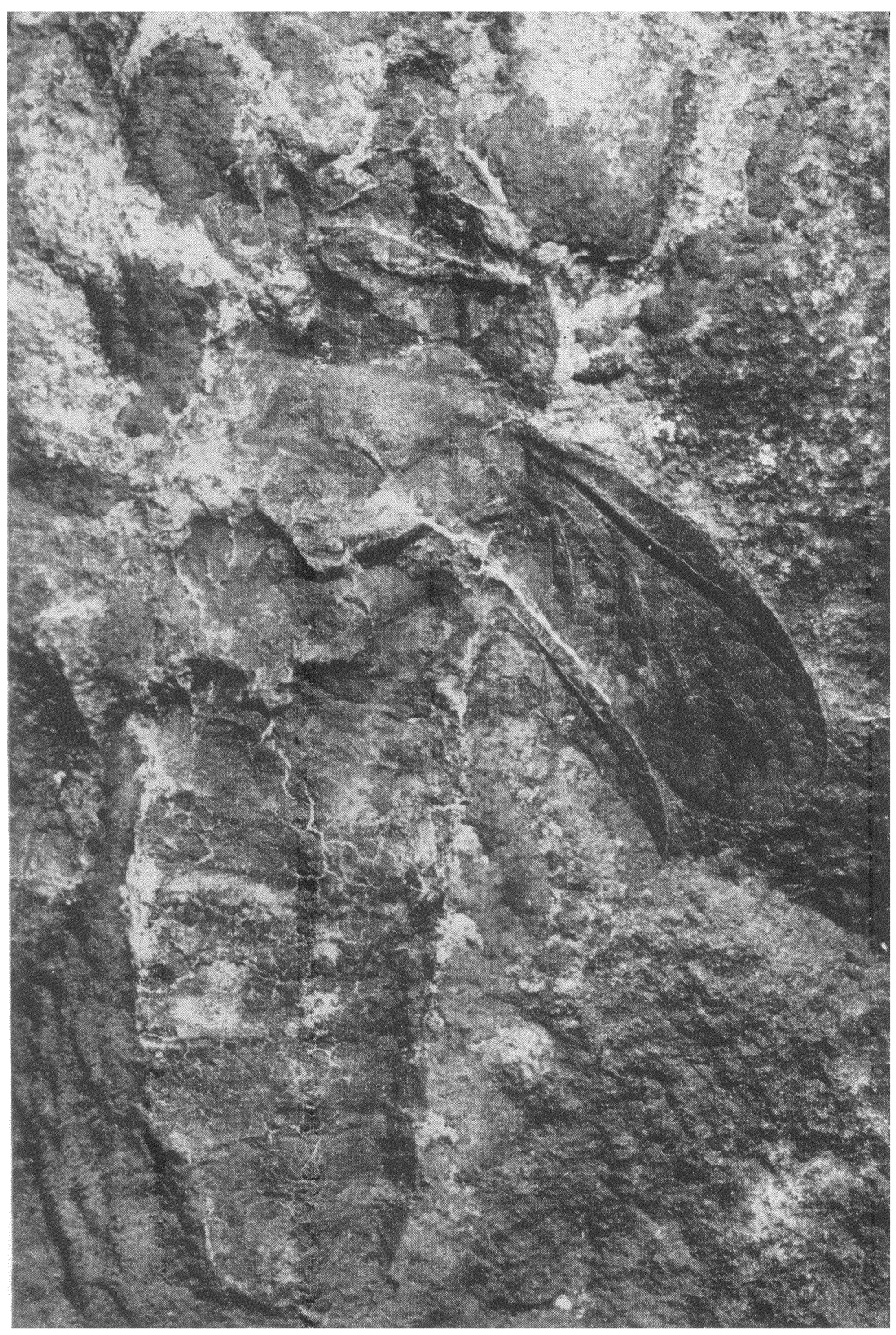

Figure 16. Herdina mirificus, n.sp. Photograph of holotype, No. H 412b, Herdina collection (reverse). 


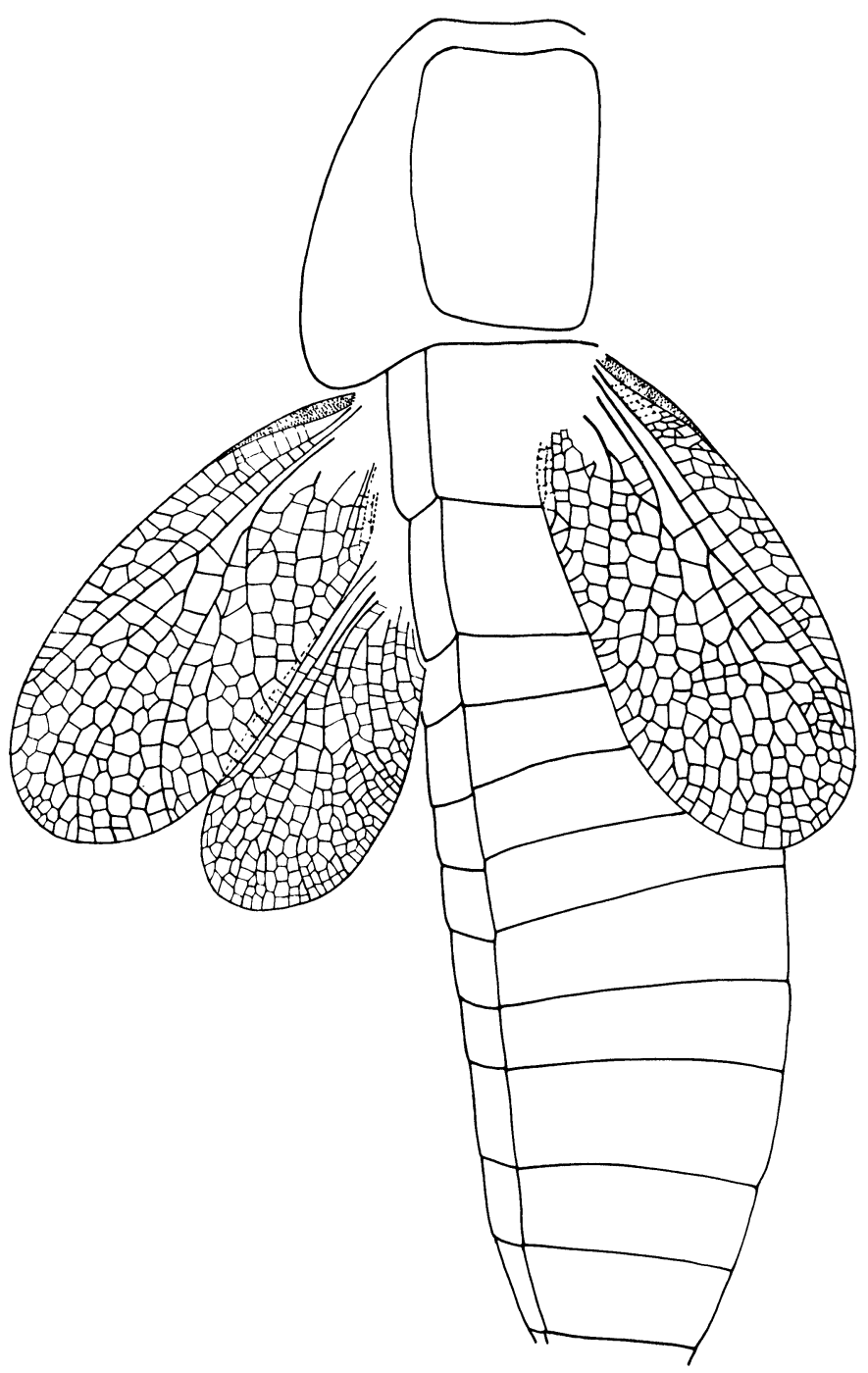

Figure 17. Herdina mirificus, n.sp. Drawing of holotype, No. H 412a, b, Herdina collection. 


\section{Genus Herdina, new genus}

Fore and hind wings short, the fore wing extending to about the middle of the abdomen. ${ }^{10}$ Fore wing: longitudinal veins, including Sc and RI, somewhat irregular, cross veins unusually strong, nearly as thick as the longitudinal veins; costal area moderately broad, with two rows of irregular cells along most of the area; Rs forking into two main branches shortly after its origin at about mid-wing; secondary branching irregular, with short rows of convex intercalary veins between the normal branches of Rs; MP apparently with one prominent branch arising at about mid-wing; $\mathrm{CuA}$ apparently unbranched; $\mathrm{CuP}$ forked shortly after its origin, one branch directed towards the hind margin; between $\mathrm{CuP}$ and $\mathrm{CuA}$ is a short, irregular intercalary vein; anal veins very weakly developed and irregular. Hind wing: costal area narrow; venational pattern basically similar to that of the fore wing, including $\mathrm{CuA}$ and $\mathrm{CuP}$.

\section{Type species: Herdina mirificus, n.sp.}

The genus is named for Mr. Jerry Herdina, of Berwyn, Illinois, in recognition of the contribution which he has made to insect paleontology through his extensive and remarkable collection of arthropods, preserved in the Mazon Creek nodules.

\section{Herdina mirificus, n.sp.}

Figures $15-20$

Fore wing: length, $8 \mathrm{~mm}$.; width, $3.5 \mathrm{~mm}$.; hind wing: length, $5.5 \mathrm{~mm}$.; width, $2.3 \mathrm{~mm}$.; length of prothorax, $5 \mathrm{~mm}$.; length of abdomen, Io $\mathrm{mm}$. It is virtually impossible to assign other specific characters for this species; venational details are shown in figures I7 and I8. As can be seen from these figures, there are some differences in the venation of the two right wings, such as in the amount of the irregularity of the longitudinal veins and the shapes of the various cells of the wings; but these are within the normal range of variation in the species of Recent Orthoptera.

Holotype: No. H 4I2a and b (obverse and reverse) in the collection of Mr. Jerry Herdina, Berwyn, Illinois; it was collected at Pit Eleven. The specimen consists of two fore wings and one hind wing, as well as parts of the thorax and abdomen.*

There are several remarkable and puzzling features about this fossil. As can be seen from comparison of the obverse and reverse

\footnotetext{
${ }^{10}$ The brachypterous condition is here treated as a generic characteristic but it could equally well be a specific or an individual trait.

*A second specimen of Herdina has just been found $(5 / 27 / 72)$ in the ironstone nodules (Wolff collection). It will be discussed in another article.
} 

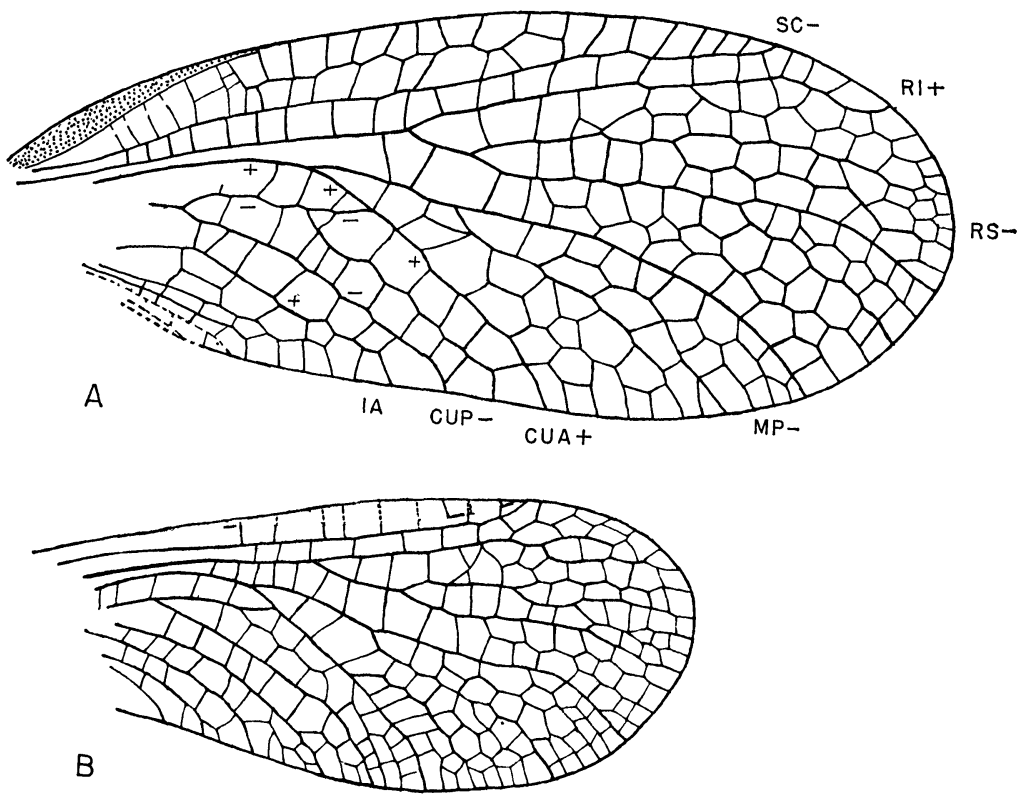

Figure 18. Herdina mirificus, n.sp. Drawing of fore and hind wings of holotype.

halves of the specimen, (figures 15 and 16 ), the counterparts appear to be very different. The reverse (figure 15, with the subcosta convex) shows the wings and thorax clearly; there is a large pronotum expanded into a dorsal shield, not unlike that known in some other Protorthoptera; only one side of the shield is preserved in the specimen. The pronotum and the rest of the thorax are apparently strongly sclerotized; the other thoracic and the abdominal segments are apparently preserved in a somewhat twisted position, so that parts of a pleuron and of the tergum of each segment are visible. The full size of the abdomen is not indicated in the reverse but is shown in the obverse (figure I6).

The wings are very clearly preseved in the reverse. They are not so distinct in the obverse but their convexities or concavities are very clear. In the reverse half, all of the veins, including the cross veins, possess prominent pits or depressions, these being almost contiguous along the veins; they are especially evident in the reverse half, where the pits are filled with a white matrix (figure 20). In the obverse, which represents the wing as seen from above, the struc- 


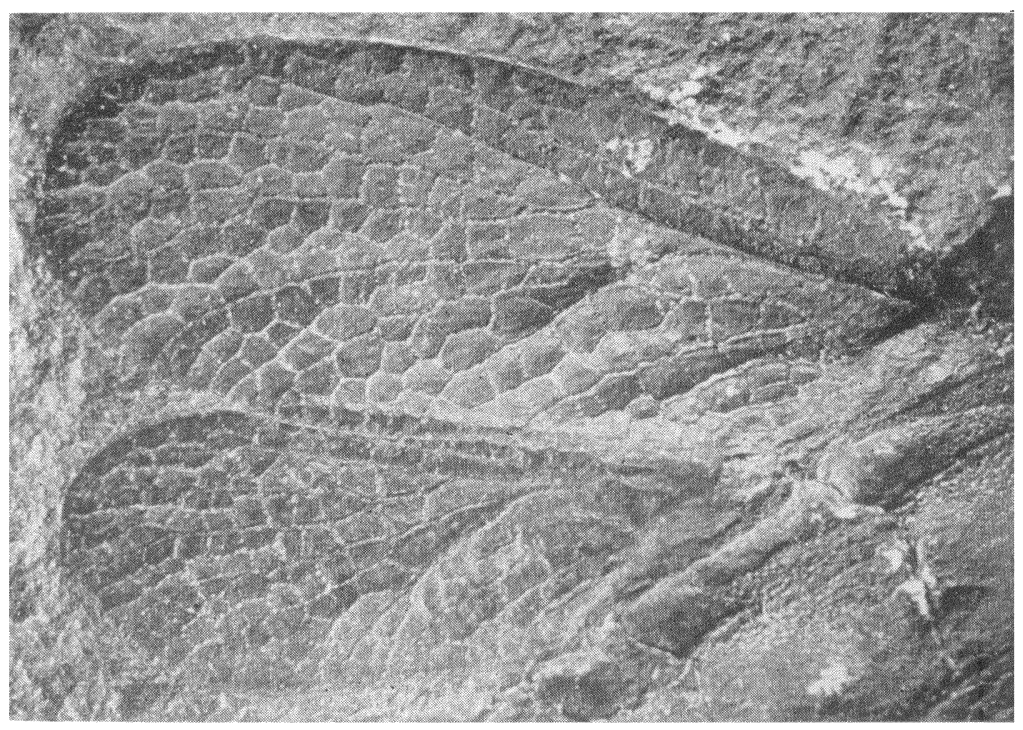

Figure 19. Herdina mirificus, n.sp. Photograph of fore and hind wings of holotype, No. H 412a, Herdina collection (obverse).

tures are in the form of bluntly rounded projections or tubercles; they do not seem to be setae. ${ }^{11}$

At first glance, one might consider the type specimen of Herdina mirificus, with its short wings, to be a nymphal form, rather than an adult. However, there are several major points against this interpretation. The most important of these is the obvious nature of the wings, themselves; they are not wing pads, included in a wing sheath, but are fully sclerotized, with a definite venational pattern, including all cross veins. Furthermore, the wings themselves are not like those of any neopterous nymph known; they are independent of each other and not attached to the adjacent part of the thoracic wall of the insect, as they are in all Recent nymphal forms. It might be argued that the insect represents a newly hatched adult in which the wings had not yet reached full development. If this were the case, it seems most unlikely that the veins in the wings would be so distinctly and clearly preserved. Actually, the occurrence of brachyptery among the Protorthoptera is not surprising, in view of the

\footnotetext{
${ }^{11}$ If figure 20 is held in an inverted position, the veins will appear to most readers as they are in the obverse half of the fossil.
} 


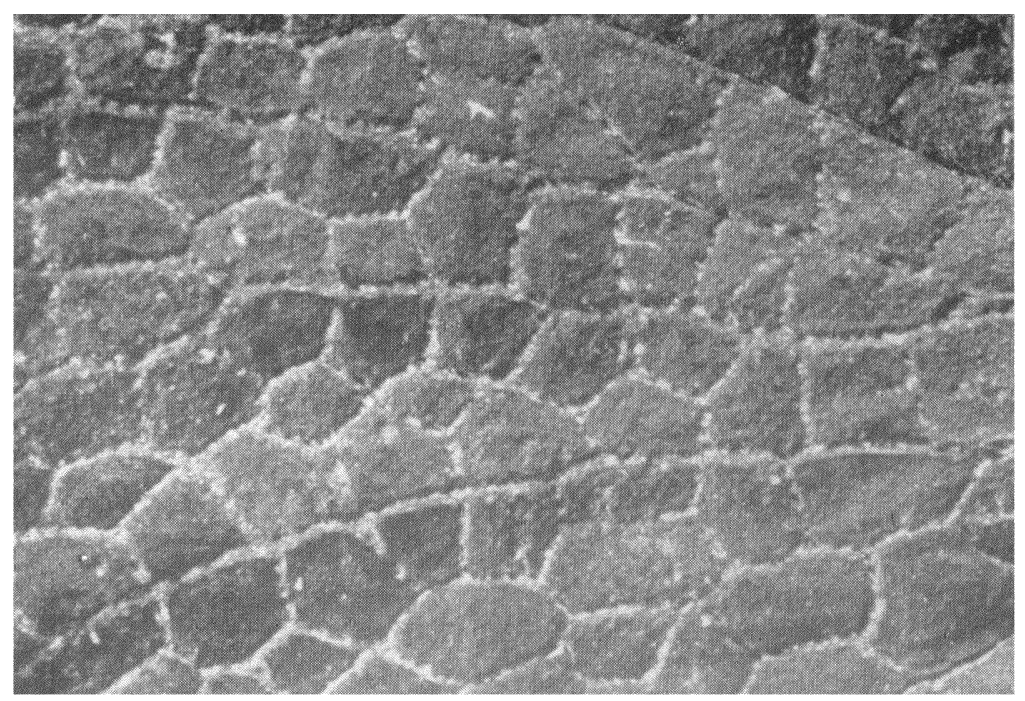

Figure 20. Herdina mirificus, n.sp. Photograph of central portion of fore wing of holotype, No. H 412a, Herdina collection, showing the details of veins and the tubercles along the veins.

frequency with which this condition is found among existing orthopteroids, such as the Orthoptera, Phasmatodea, Blattodea, etc.

Although the slender band of sclerotization at the base of the costal margin is unusual, it is by no means unique; sclerotized areas, diversely located, have been found in other orthopteroids, such as Nacekomia rossae Richardson (also from the Francis Creek Shale). The venation of the wings in Herdina has many of the same features as those of the Cacurgidae, as noted above. The most distinctive characteristic is the irregularity of the main veins; this is undoubtedly associated with the thickness of the cross veins, which are only slightly less heavy than the main veins. The relatively small size of the hind wing of Herdina is also not surprising in itself; its most striking and significant feature is the similarity of its venation to that of the fore wing. In all of the Protorthoptera in which the hind wing is known, and in the Orthoptera as well, the venation of the hind wing is distinctly different from that of the fore wing; Rs arises much nearer the base of the wing; $\mathrm{CuA}$ is unbranched; and the anal area is enlarged, with several additional anal veins. Herdina is the first instance known of an otherwise typically protorthopterous insect in which the fore and hind wings are virtually homonomous in venational pattern. Unfortunately, nothing is known of the hind wings of those Protorthoptera which appear to 
be closely related to Herdina, i.e. the Cacurgidae and Omaliidae. Hence, we do not know if the hind wing venation in these families was like that of other Protorthoptera or if it was like that of the fore wings, as in Herdina. Such a condition does occur, however, among several existing orders of Neoptera (Isoptera and Embioptera, for example). In these the homonomous condition is apparently derived from a previous heteronomous one; the same was almost certainly true for the Herdinidae.

\section{Carpenter, F. M.}

\section{REFERENCES}

1964. Studies on North American Carboniferous insects. 3. A spilapterid from the vicinity of Mazon Creek, Illinois (Palaeodictyoptera). Psyche 71: 117-124.

1967. Studies on North American Carboniferous insects. 5. Palaeodictyoptera and Megasecoptera from Illinois and Tennessee, with a discussion of the Order Sypharopteroidea. Psyche 74: 58-84.

1971. Fossil insects from New Mexico. Psyche 77: 400-412.

Carpenter, F. M. and E. S. Richardson, Jr.

1968. Megasecopterous nymphs in Pennsylvanian concretions. Psyche 75: 295-309.

Crampton, G. C.

1927. Eugereon and the ancestry of the Hemiptera, psocids, and Hymenoptera. Bull. Brook. Ent. Soc. 22: 1-17.

GOLDENBERG, F.

1854. Die fossilen Insekten der Kohlenformation von Saarbrücken.

GUTHÖL, P. Palaeontogr. 4: 17-38.

1934. Die Arthropoden aus dem Karbon und Perm des Saar-NahePfalz-Gebietes. Preuss. Geol. Landes., Abhandl. N.F. 164: 7376.

HandLiRSCH, A.

1911. New Falaeozoic insects from the vicinity of Mazon Creek, Illinois. Amer. Journ. Sci. (5) $31: 374$.

1920. Palaeontologie. In Schröder, Handbuch der Entomologie. 3: 129. Kukalová, J.

1.968. Permian mayfly nymphs. Psyche $75: 310-327$.

1969-1970. Revisional study of the Order Palaeodictyoptera in the Upper Carboniferous shales of Commentry, France. Psyche 76: $163-215 ; 439-486 ; 77: 1-44$.

LaUrentiaux, D.

1952. Découverte d'un rostre chez Stenod ctya lobata Brgt. (Paléodictyoptère sténodictyide) et le problème des Protohémiptères. Bull. Soc. Géol. France, 2: 233-247.

1953. Classes des Insectes. In Traité de Paléontologie (Piveteau), Paris. 3: 415 .

LAMEere, A.

1933. Précis de Zoologie. $4: 255-256$.

SChLECHTENDAL, D. $v$.

1912. Untersuchung über die karbonischen Insekten und Spinnen von Wettin unter Berucksichtigung verwandter Faunen. Abhandl. Kaiserlichen Leopold. -Carol. Deutsch. Acad. Natur. 98: 119-124. 

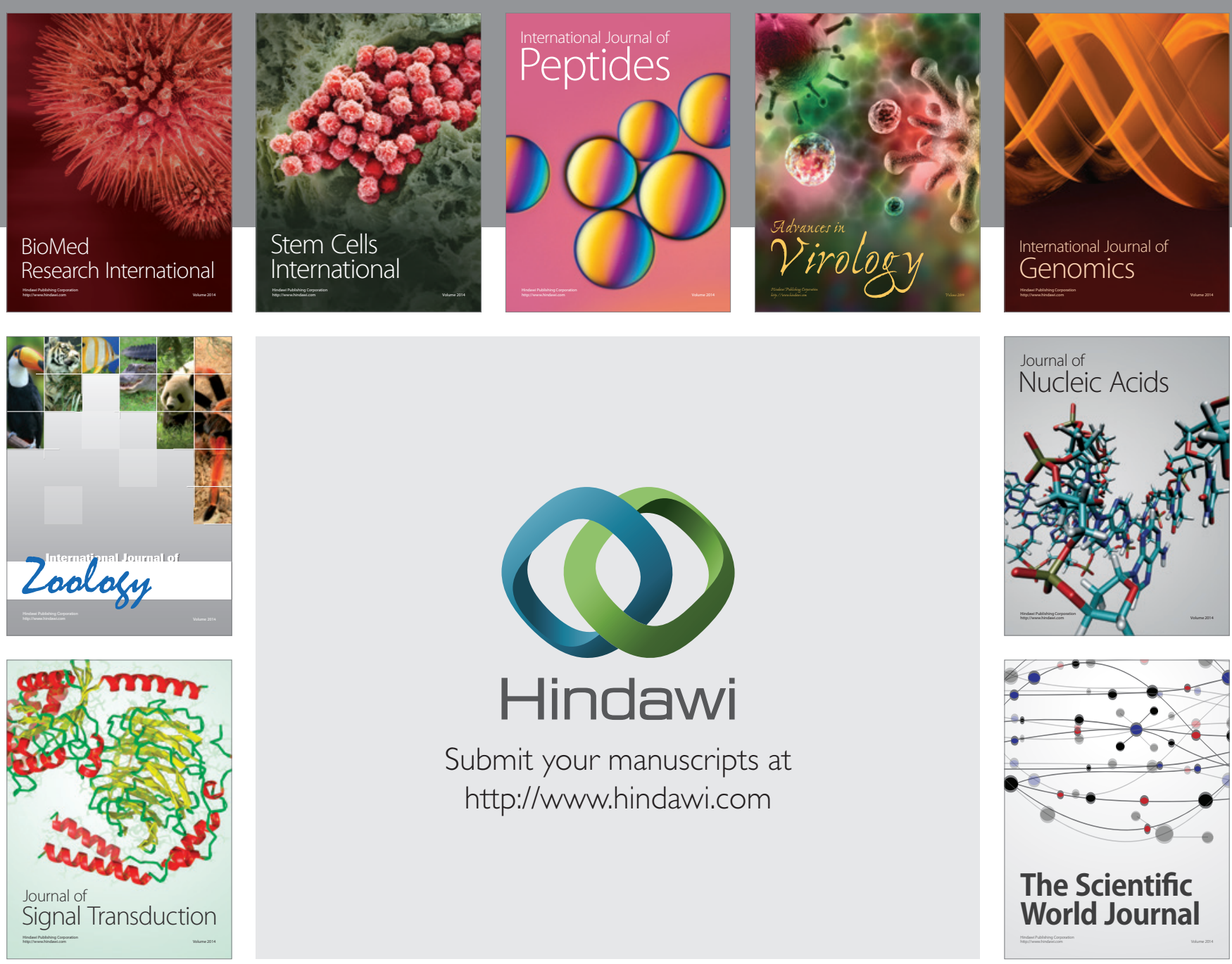

Submit your manuscripts at

http://www.hindawi.com
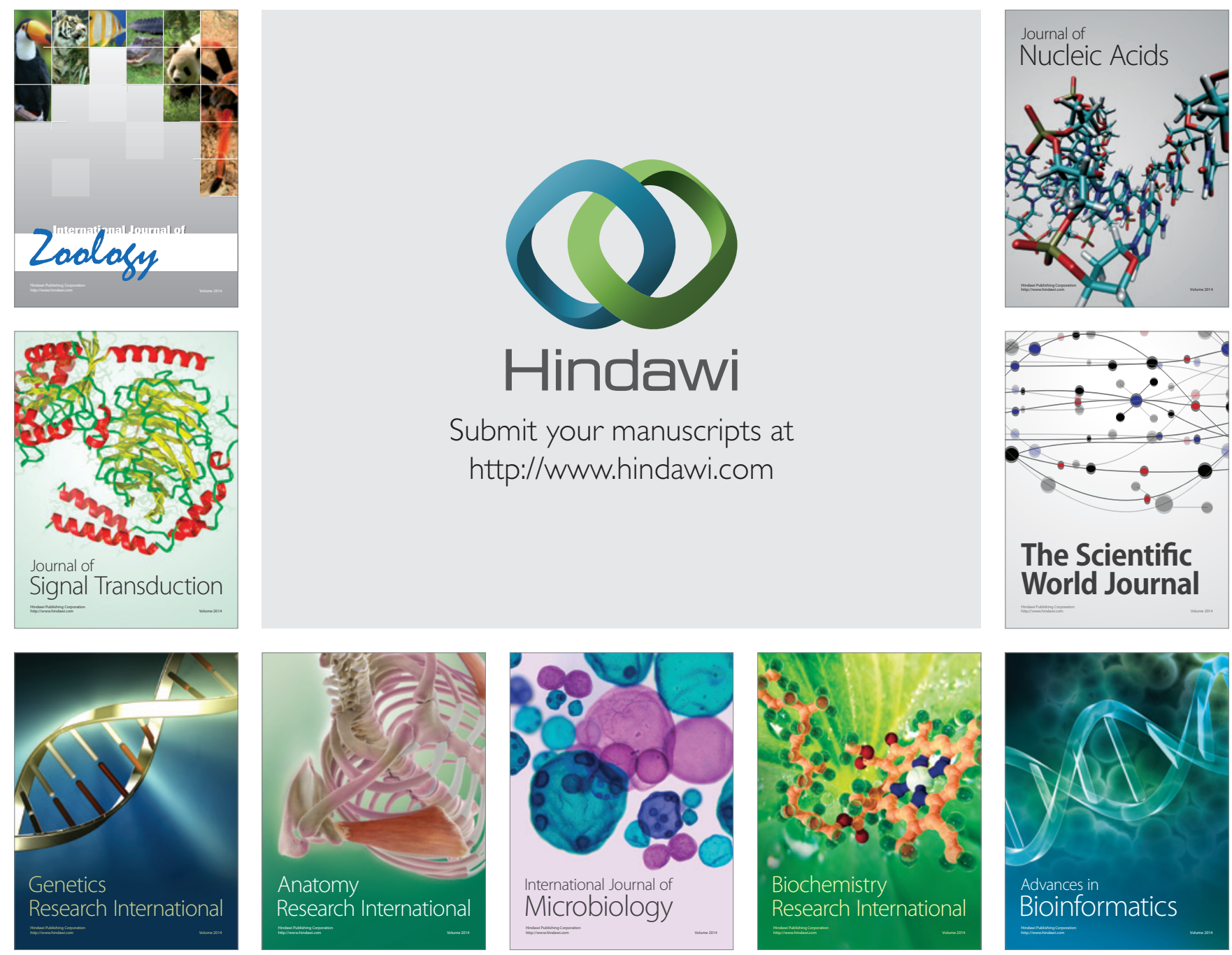

The Scientific World Journal
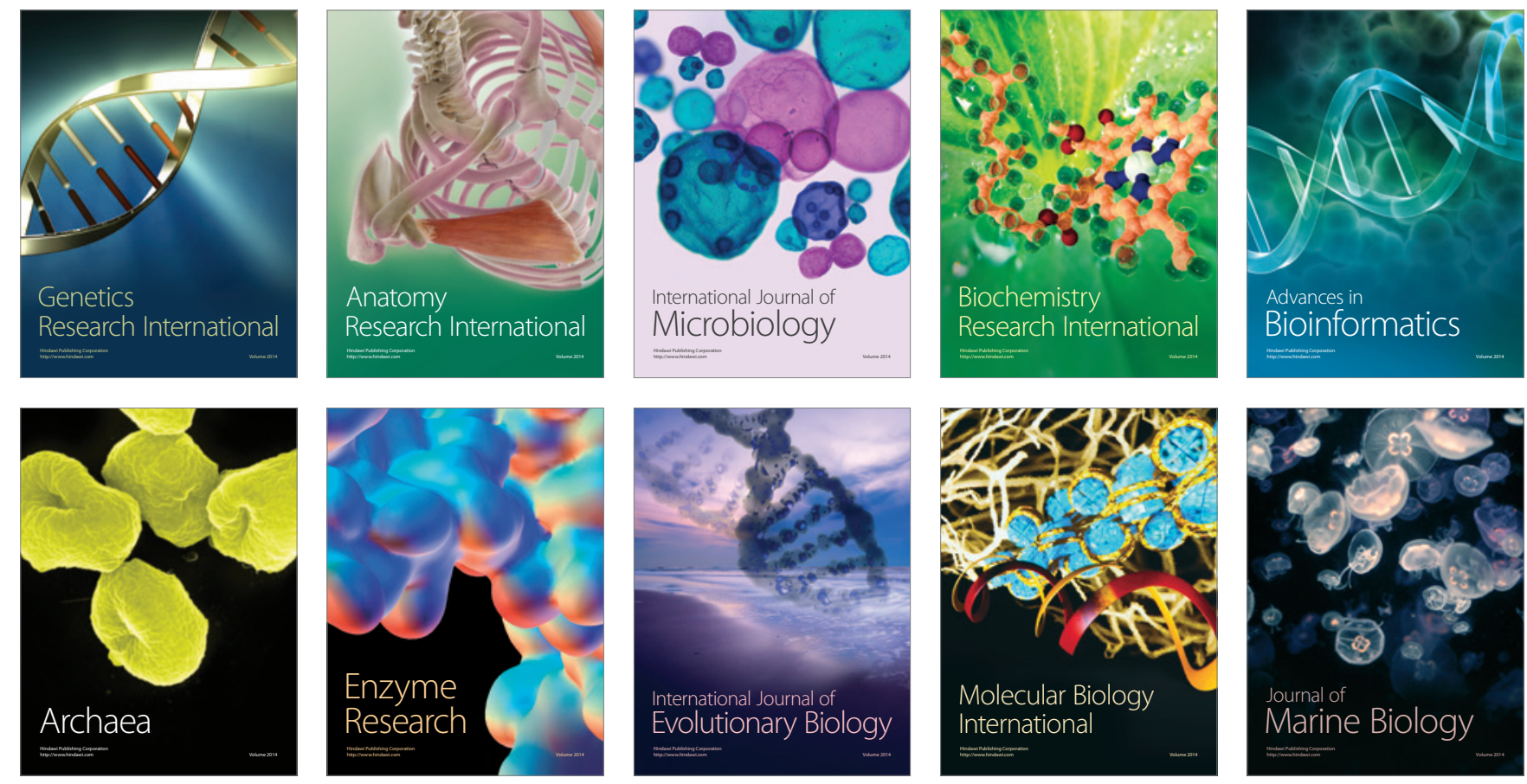